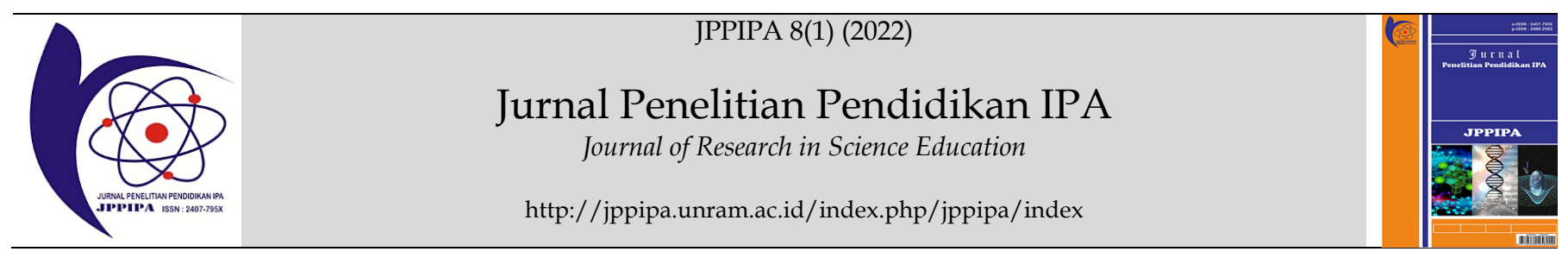

\title{
The Effect of 3T School Digitalization in the Era of the COVID-19 Pandemic
}

\author{
Ana Silfiani Rahmawati ${ }^{*}$, Daniel Wolo ${ }^{1}$ \\ ${ }_{1}^{1}$ Physics Education Study Program, Flores University, Ende, Indonesia.
}

DOI: $10.29303 /$ ippipa.v8i1.1180

\section{Article Info}

Received: November 28, 2021

Revised: January 10, 2022

Accepted: January 22, 2022

Published: January 31, 2022

\begin{abstract}
This study aims to determine whether digitizing 3T schools in the era of the covid 19 virus pandemic. The type of research used is survey research using quantitative descriptive analysis. The research design is Ex-Post Facto. The subjects in this study are schools included in the 3T region (frontier, outermost, and underdeveloped) in Indonesia, especially in the East Nusa Tenggara region. The object of this study was 40 3T school teachers in four districts on the island of Flores (Nagakeo Regency, East Manggarai Regency, Manggarai Regency, and West Manggarai). The results showed that the number of respondents who answered in the agree category got the highest number, namely 19 people with a percentage of $47 \%$. In the strongly agree category, there were 16 people with a percentage of $40 \%$, the category did not agree. Five people with a percentage of $13 \%$, and none. Who chose the category strongly disagree (percentage $0 \%$ ). From this, it can be concluded that school digitization has a positive effect during the COVID-19 pandemic; this can be seen from the number of teachers in the 3T region who chose the agreed category, namely 19 people $(47 \%)$.
\end{abstract}

Keywords: Digitization; COVID-19; Teacher; Flores; 3T region.

Citation: Rahmawati, A.S., \& Wolo, D. (2022). The Effect of 3T School Digitalization in the Era of the COVID-19 Pandemic. Jurnal Penelitian Pendidikan IPA, 8(1), 341-345. https://doi.org/10.29303/jppipa.v8i1.1180

\section{Introduction}

In December 2019, pneumonia of unknown origin was reported in Wuhan, Hubei Province, China. Analysis of its genome showed the virus as a new coronavirus related to SARS-CoV, hence the name severe acute respiratory syndrome coronavirus (Ciotti, et al., 2020; Fathurrahim, et al., 2021). This virus quickly spread to other countries and, in a short time, became a world pandemic. This virus is known as the covid 19 virus or coronavirus disease. Indonesia is no exception. Indonesia is also part of one of the countries affected by the COVID-19 pandemic. This virus has also affected the world of education, where the teaching and learning process, which is usually carried out face to face in classrooms, must be carried out through distance learning (PJJ) with the use of technology. Information (Damopolii, Lumembang, \& İlhan, 2021; Pakpahan \& Fitriani, 2020; Raiman, et al., 2021; Yurida, et al., 2021)
Technological developments are happening very fast and have become part of human life (Hakim, et al., 2021). The technology developed can provide great benefits and influence on human life (Sari, 2019). (Ammah, 2018) states that in the world of education, learning must adapt and update itself to be compatible with the global world so that it can compete with modern society in today's digital world. In Indonesia, the use of digital media has grown rapidly (Affifatusholihah, et al., 2021).

Information and Communication Technology (ICT) is also beneficial for students to become active learners by creating content for viewers throughout the archipelago or the world. As we know, in the era of the industrial revolution 4.0, technological advances greatly affect the quality of people's lives. In line with government policies, 3T schools also implement these policies. 3T schools are schools that are in the front, outermost, and underdeveloped zones in Indonesia. The policy of distance learning (PJJ) and online learning 
(Daring) greatly affects students in the $3 \mathrm{~T}$ area. On the other hand, students must learn contextually and inquiry-based (Aco, et al., 2021; Bhure, et al., 2021; Lelasari, et al., 2021; Mandasari, et al. 2021; Ruto, et al., 2021).

The Ministry of Education and Culture emphasized expanding access to education for 3T schools through the school digitization program. The digitalization of schools is the answer to the challenges of the industrial revolution. School digitization is the implementation of new learning prepared to face the industrial revolution 4.0 (Ansari, 2020). However, the 3T school digitization program has not been in line with the Human Resources (HR) level in the 3T area, especially for the students.

Digitization of learning is one of the current challenges schools face in Indonesia, including for schools in remote areas (Damopolii \& Kurniadi, 2019a; Damopolii \& Kurniadi, 2019b; Dirckinck-Holmfeld et al., 2019; Nugraha \& Anggraini, 2019). Students who do not have or cannot even use gadgets (laptops and cellphones) are the main problem. In addition, the condition of the area that still lacks infrastructure is also an obstacle, for example, the absence of electricity in schools, the absence of an internet network, or areas that have not been able to capture cellphone signals. This study aims to determine whether there is an effect of digitizing 3T schools in the era of the covid 19 virus pandemic.

\section{Method}

The type of research used is survey research using quantitative descriptive analysis. The research design is Ex-Post Facto. The research design can be described in figure 2.

\section{$\mathrm{X} \longrightarrow \mathrm{Y}$}

Figure 2. Design ex-post-facto

Description:

X: Digitalization 3T School

Y: Covid 19 Pandemic

\section{Result and Discussion}

This study was conducted to determine whether there is an effect of digitizing 3T schools in the era of the covid 19 pandemic. The study analyzed data from 40 respondents who filled out questionnaires or questionnaires distributed by researchers to teachers who served in 3T areas. The questionnaire consists of 30 questions and statements. Data from filling out the questionnaire, then analyzed by tabulating. The scores and scores are calculated, then the categories are searched. The categories in this study consisted of four categories that were adjusted to the scores in the research questionnaire, namely strongly agree, agree, disagree, and strongly disagree. From the calculation of the questionnaire, obtained the total score and value for each respondent, which is then from the total score and average value, minimum value, maximum value, standard deviation, and variance (can be seen in Table 1).

Table 1. Total Score and Value of Each Respondent

\begin{tabular}{|c|c|c|}
\hline \multirow{2}{*}{ Respondent } & \multicolumn{2}{|l|}{ Total } \\
\hline & Score & Value \\
\hline 1 & 103 & 86 \\
\hline 2 & 77 & 64 \\
\hline 3 & 118 & 98 \\
\hline 4 & 78 & 65 \\
\hline 5 & 85 & 71 \\
\hline 6 & 86 & 72 \\
\hline 7 & 88 & 73 \\
\hline 8 & 102 & 85 \\
\hline 9 & 96 & 80 \\
\hline 10 & 86 & 72 \\
\hline 11 & 109 & 91 \\
\hline 12 & 93 & 78 \\
\hline 13 & 91 & 76 \\
\hline 14 & 106 & 88 \\
\hline 15 & 107 & 89 \\
\hline 16 & 102 & 85 \\
\hline 17 & 101 & 84 \\
\hline 18 & 101 & 84 \\
\hline 19 & 77 & 64 \\
\hline 20 & 68 & 57 \\
\hline 21 & 96 & 80 \\
\hline 22 & 62 & 52 \\
\hline 23 & 76 & 63 \\
\hline 24 & 65 & 54 \\
\hline 25 & 66 & 55 \\
\hline 26 & 87 & 73 \\
\hline 27 & 64 & 53 \\
\hline 28 & 85 & 71 \\
\hline 29 & 107 & 89 \\
\hline 30 & 94 & 78 \\
\hline 31 & 109 & 91 \\
\hline 32 & 103 & 86 \\
\hline 33 & 102 & 85 \\
\hline 34 & 105 & 88 \\
\hline 35 & 92 & 77 \\
\hline 36 & 95 & 79 \\
\hline 37 & 102 & 85 \\
\hline 38 & 94 & 78 \\
\hline 39 & 92 & 77 \\
\hline 40 & 102 & 85 \\
\hline Average & 92 & 77 \\
\hline Minimum & 62 & 52 \\
\hline Maximal & 118 & 98 \\
\hline Std Deviation & 14 & 12 \\
\hline Variant & 200 & 139 \\
\hline
\end{tabular}

From the total score and value obtained, look for the maximum amount, minimum amount, average mortgage, and mortgage standard deviation (score and value). The results can be seen in Table 2 . 
Table 2. Maximum, Minimum, Average Mortgage, and Mortgage Standard Deviation for Score and Value

\begin{tabular}{lll}
\hline Criteria & Score & Value \\
\hline Maximum & 120 & 100 \\
Minimum & 30 & 25 \\
Average Mortgage & 75 & 63 \\
Mortgage Standard Deviation & 23 & 19 \\
\hline
\end{tabular}

From Table 2. it can be seen that the maximum number for the score is 120 , while for the score is 100; the minimum number for the score is 30 , while the score is 25 ; the average mortgage score for the score is 75 , while the score is 63; and the standard deviation for the score is 23 , while the value is 19 . After getting the results from Table 2, it is continued by looking for the number of respondents per category. As explained earlier, there are four categories in this study, namely strongly agree, agree, disagree, and strongly disagree. The number of respondents per category can be seen in Table 3 .

Table 3. Number of Respondents Per Category

\begin{tabular}{ll}
\hline Category & Respondents \\
\hline Strongly agree & 16 \\
Agree & 19 \\
Disagree & 5 \\
Strongly disagree & 0 \\
Total & 40 \\
\hline
\end{tabular}

From Table 3. it can be seen that the number of respondents who strongly agree is 16 people, agrees 19 people, disagrees five people, and strongly disagrees 0 . From this number, we can also look for the percentage of each category. The percentage can be seen in Figure 2 .

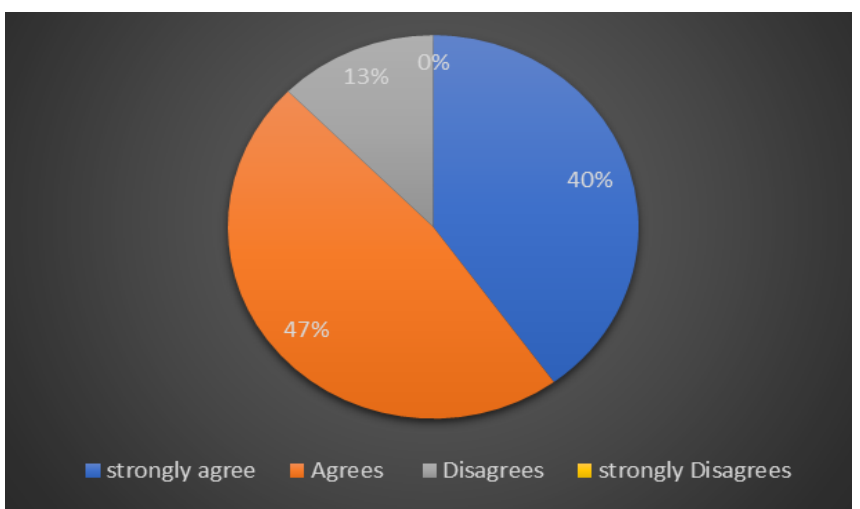

Figure 2. Respondent Category Percentage

From Figure 2, it can be seen, the percentage for the category strongly agree is $40 \%$, the category agrees $47 \%$, the category disagrees $13 \%$, and the category strongly disagrees $0 \%$. The contents of tables and figures are the same thing but in different forms. Table 3 is the sum of the respondents in each category which can be seen in the form of numbers, while Figure 2 is the sum of the respondents which is presented in the form of a pie chart. This is necessary so that we can know the number of each category in the form of numbers and the percentage of each respondent in each category.

Teachers are the determinant of the success of learning in schools (Sadipun \& Wangge, 2020). Based on the data from the research results, it can be seen that the agree category ranks at the top of the most, followed by the category strongly agree, disagree and the last one strongly disagrees. This shows that the respondents chose to agree with the implementation of school digitization in the $3 \mathrm{~T}$ area. Respondents also stated that school digitization had a significant influence during the COVID-19 pandemic in the 3T area, especially in the NTT area (Flores Island). Based on the researchers' findings, it can be said that digitalization in schools in the 3T area had a positive influence during the pandemic. The results obtained are in line with those found by Viberg et al. (Roumbanis Viberg, et al., 2020) who found that teachers have demands to use and teach with digital technology. Digitalization-based learners became an alternative solution for completing teaching and learning activities (Salkiah, 2020). Even though it is a 3T area, the use of technology must also be made. Teachers must be innovative. Our findings reveal that teachers agree that technology and digitization have impacted their learning during COVID-19.

\section{Conclusion}

From the results of the research conducted, it can be seen that the number of respondents who answered in the agree category got the most number, namely 19 people with a percentage of $47 \%$, then in the strongly agree category there were 16 people with a percentage of $40 \%$, the category disagreed with five people with a percentage of $13 \%$. No one chose the category strongly disagree ( $0 \%$ percentage). From this, it can be concluded that school digitization had a positive influence during the COVID-19 pandemic; this is seen from a large number of teachers in the 3T area who chose the agree category, namely 19 people $(47 \%)$.

\section{Acknowledgments}

The researcher would like to thank the Ministry of Education and Culture-RISTEK, which has provided budget support for the research provided in the Beginner Lecturer Research (PDP) scheme. The researcher also thanks the teachers who have taken the time to provide answers/responses to the questionnaires distributed/sent.

\section{References}

Aco, S. N., Rahman, S. R., \& Firman, F. (2021). Using inquiry-based learning to strengthen student learning outcomes. Journal of Research in 
Instructional,

1(1),

https://doi.org/10.30862/jri.v1i1.2

$1-12$.

Affifatusholihah, L., Putri, S. I., \& Hanun, D. I. (2021). Analisis faktor yang mempengaruhi aplikasi investasi digital. Media Bina Ilmiah, 16(4), 66276634. https:// doi.org/10.33758/mbi.v16i3.1306

Ammah, E. S. (2018). Integrating technology in Indonesian Language Learning. Jakarta: Syair Gema Maulana Press.

Ansari, K. (2020). Arah Pembelajaran Bahasa dan Sastra Indonesia Pada Era Industri 4.0. Medan: Pustaka Diksi Medan.

Bhure, M., Welu, F., See, S., \& Ota, M. K. (2021). The effort to enhance pupils' cognitive learning achievement using contextual teaching and learning approach. Journal of Research in Instructional, 1(1), 13-22. https://doi.org/10.30862/jri.v1i1.3

Ciotti, M., Ciccozzi, M., Terrinoni, A., Jiang, W.-C., Wang, C.-B., \& Bernardini, S. (2020). The COVID19 pandemic. Critical Reviews in Clinical Laboratory Sciences, 57(6), 365-388. https://doi.org/10.1080/10408363.2020.1783198

Damopolii, I., \& Kurniadi, B. (2019). Training students metacognitive skills using mobile learning. Journal of Physics: Conference Series, 1317(1), 012185. https://doi.org/10.1088/17426596/1317/1/012185

Damopolii, Insar, \& Kurniadi, B. (2019). The Development of Android-based Mobile Learning Supported by Problem-based Learning Strategy for Students' Learning Success. Int. J. Sci. Technol. Res, 8(7), 190-193.

Damopolii, Insar, Lumembang, T., \& İlhan, G. O. (2021). Digital Comics in Online Learning During COVID19: Its Effect on Student Cognitive Learning Outcomes. International Journal of Interactive Mobile Technologies (IJIM), 15(19), 33-47. https://doi.org/10.3991/ijim.v15i19.23395

Dirckinck-Holmfeld, L., Ipsen, B. J., Tamborg, A. L., Dreyøe, J., Allsopp, B. B., \& Misfeldt, M. (2019). Modes of Teacher Participation in the Digitalization of School. Designs for Learning, 11(1), 63-71. https://doi.org/10.16993/dfl.109

Fathurrahim, F., Habibi, P., Jumail, M., \& Mahsun, M. (2021). Studi komparasi tentang kemampuan belajar mandiri, kemampuan penggunaan it dan produktivitas kerja civitas STP Mataram sebelum pandemi dan pada masa pandemi COVID-19. Media Bina Ilmiah, 16(1), 6165-6176. https://doi.org/10.33758/mbi.v16i1.1221

Hakim, A. R., Widhi, M. T. W., \& Admoko, S. (2021). Sistem Pengaman Berbasis Microcontroler Internet Of Things (IoT) Sebagai Pengaman Rumah Interaktif. Jurnal Pendidikan Fisika Dan Teknologi, 7(1), 43. https://doi.org/10.29303/jpft.v7i1.2707
Lelasari, T., Yohanita, A. M., \& Damopolii, I. (2021). Effect of inquiry science learning on students' metacognitive skill. Journal of Research in Instructional, 1(1), 53-60. https://doi.org/10.30862/jri.v1i1.12

Mandasari, F., Iwan, I., \& Damopolii, I. (2021). The relationship between science process skills and biology learning outcome. Journal of Research in Instructional, 1(1),

23-32. https://doi.org/10.30862/jri.v1i1.9

Nugraha, D., \& Anggraini, Y. (2019). Digitalisasi Pembelajaran Di Sekolah Pedalaman (Implementasi Pembelajaran Berbasis Komputer di SD Bina Dharma Muara Tiga dan Kebun Sentral Sumatera Utara). Jurnal Pendidikan Dasar Setiabudhi, 3(1), 1-10. Retrieved from https://stkipsetiabudhi.ejournal.id/ipds/article/view/33

Pakpahan, R., \& Fitriani, Y. (2020). Analisa Pemanfaatan Teknologi Informasi Dalam Pembelajaran Jarak Jauh Di Tengah Pandemi Virus Corona Covid-19. Journal Of Information System, Applied, Management, Accounting And Research (JISAMAR), 4(2), 30-36. Retrieved from http://journal.stmikjayakarta.ac.id/index.php/jis amar/article/view/181

Raiman, M., Liu, A. N. A. M., \& Wolo, D. (2021). Investigation of students' motivation to learn science while studying from home during a pandemic. Journal of Research in Instructional, 1(1), 33-42. https:// doi.org/10.30862/jri.v1i1.10

Roumbanis Viberg, A., Forslund Frykedal, K., \& Sofkova Hashemi, S. (2020). Teacher educators' perceptions of their profession in relation to the digitalization of society. Journal of Praxis in Higher Education, 1(1), 87-110. https:// doi.org/10.47989/kpdc80

Ruto, R., Mema, A., Nduru, M. P., \& Ota, M. K. (2021). Contextual teaching and learning approach in social science: its role to encourage pupils' cognitive learning achievement. Journal of Research in Instructional, 1(1), 43-52. https://doi.org/10.30862/jri.v1i1.11

Sadipun, B., \& Wangge, Y. S. (2020). Kompetensi pedagogik guru SD di Gugus V Kecamatan Nangapanda Kabupaten Ende tahun ajaran 2017/2018. Media Bina Ilmiah, 15(4), 4263-4270. https://doi.org/10.33758/mbi.v15i4.775

Salkiah, B. (2020). Perubahan paradigma pendidikan dan ekonomi dimasa pandemi COVID-19. Media Bina Ilmiah, 15(1), 3781-3788. https://doi.org/10.33758/mbi.v15i1.647

Sari, R. I. (2019). Analisis Tingkat Kemandirian Belajar Siswa Pada Mata Pelajaran Fisika Kelas XII MAN 1 Batang Hari. Jurnal Pendidikan Fisika Dan Teknologi, 5(2),

296-304. 
Yurida, Y., Damopolii, I., \& Erari, S. S. (2021). Hubungan Antara Kreativitas Guru dengan Motivasi Belajar Sains Siswa selama Pandemic COVID-19. Prosiding SNPBS (Seminar Nasional Pendidikan Biologi Dan Saintek), 146-152 